\title{
Factors Affecting Job Pursuit Intention in Hotel Industry in Ho Chi Minh, Viet Nam
}

\author{
Linh Viet HOANG ${ }^{1}$, Hieu Minh VU², Vu Minh NGO ${ }^{3}$
}

Received: August 01, 2020 Revised: September 20, 2020 Accepted: October 05, 2020

\begin{abstract}
Given the rise in international tourism and the rapid growth of the Vietnamese economy, the hospitality industry in Ho Chi Minh City, Vietnam's commercial hub, has been facing severe labor shortages due to competition with other fast-growing parts of the economy. These struggles to acquire high-quality employees is strangling future growth and placing new importance on the role of recruitment. To better understand the effectiveness of an organization's recruitment strategy, recruiters need to ascertain the Job Pursuit Intention (JPI) of job seekers to efficiently align an applicant's work notions with the organization's goals. This study aims to investigate the factors impacting on JPI among employees working in the hotel sector in Ho Chi Minh City. Secondary data are from previous studies and primary data are from consultation with 10 experts, group discussions and five in-depths structured interviews with 15 random employees and 302 survey questionnaires with employees working in three five-star hotels. Cronbach's Alpha, EFA, T-Test, ANOVA are used for statistical analysis. The findings show that compensation, career advancement, and work-life balance affect JPI of job seekers, in which compensation is the most influential factor. Furthermore, recommendations for recruiters, further research and limitations of this study have been laid out.
\end{abstract}

Keywords: Career Advancement, Compensation, Corporate Social Responsibility, Hospitality Industry, Job Pursuit Intention (JPI), WorkLife Balance

JEL Classification Code: M10, I20, I23, Z30

\section{Introduction}

Hospitality industry in Ho Chi Minh City has been facing with fierce competition for human capital to meet the demand of the significantly increasing tourist numbers annually and the aggressive expansion of international hotel groups. In order to create and achieve a sustainable competitive advantage, economic profit, and long live in the increasingly globalized and competitive marketplace, human

\footnotetext{
${ }^{1}$ First Author. Graduate School, HELP University, Malaysia.

Email: hoangvietlinh124@gmail.com

${ }^{2}$ Corresponding Author. Faculty of Business Administration, Van Lang University, Ho Chi Minh City, Vietnam [Postal Address: 45 Nguyen Khac Nhu, Co Giang Ward, District 1, Ho Chi Minh City, 700000, Vietnam] Email: hieu.vm@vlu.edu.vn

${ }^{3}$ School of Banking, University of Economics Ho Chi Minh City, Vietnam. Email: ngominhvu@gmail.com

(c) Copyright: The Author(s)

This is an Open Access article distributed under the terms of the Creative Commons Attribution Non-Commercial License (https://creativecommons.org/licenses/by-nc/4.0/) which permits unrestricted non-commercial use, distribution, and reproduction in any medium, provided the original work is properly cited.
}

resource management (HRM) becomes extremely important, especially in a service-oriented, human-intensive sector that is the hospitality industry by its service industry nature.

Recruitment is the first major function of HRM and is the cornerstone of successful business in the hospitality industry (Chang \& Tanford, 2018). However, recruitment in the hotel industry becomes more challenging than in other sectors because this industry is well-known for its unwarranted use of high levels of casual workers, long and unsocial working hours, and especially low pay (George et al., 2020). For instance, Ul Islam et al. (2016) indicate that most employees working in the hotel industry in Pakistan are not satisfied with their employers due to the low remuneration. Therefore, in order to improve recruitment strategy, recruiters need to better understand job pursuit intention (JPI) of job seekers, which is defined as applicant's desire to apply for a vacant position (Williamson et al., 2003). The more candidates apply for a vacancy, the larger number of qualified applicants the organization can select from, which results in achieving more effective recruiting strategies and stronger competitive advantages over its rivals (Williamson et al., 2003). However, hospitality organizations in Ho Chi 
Minh City have not paid much attention to factors affecting JPI of employees, and the body of research related to this field is very limited. This is the gap this research seeks to fill.

During the last decade, JPI has received much interest from researchers, which results in many factors affecting JPI of potential employees such as work-life balance, work atmosphere, compensation and benefits, recognition, opportunity for development, organizational symbolism, stability of the company, job security, organizational culture, diversity, corporate social responsibility, interest value, social value, economic value, development value, application value, perceived employment experience, training and development, and job advancement (Ambler \& Barrow, 1996; Backhaus \& Tikoo, 2004; Berthon et al., 2005; Jain \& Bhatt, 2015; Tanwar \& Prasad, 2017; Zhu et al., 2014). Among these factors, compensation, work-life balance, corporate social responsibility, career advancement, and social life have been shown to be the most influential factors impacting JPI of job seekers. Understanding the reasons why job seekers pursuit employment at a specific organization and identifying impacting factors on the JPI is important to study. Therefore, this study is aiming at exploring significant factors influencing JPI of job seekers in Ho Chi Minh City with the aim to assist hospitality organizations in building a better recruitment strategy.

\section{Literature Review}

\subsection{Signaling Theory}

To build the conceptual framework that involves factors affecting JPI, the signaling theory (Rynes et al., 1991) has been used as the primary frame. The theory emphasizes that neither prospective employee nor employer has complete information about each other's preferences (Ehrhart \& Ziegert, 2005). Therefore, through the entire process of seeking employment, prospective applicants need the company to signal its characteristics as an employer to reduce information asymmetries (Cable \& Turban, 2003; Wang, 2013). The prospective candidates then utilize such information to shape their stances about what it would look like to work for that company (Celani \& Singh, 2011; Greening \& Turban, 2000). Hence, understanding their perspectives on JPI is crucial, and the organization can develop an effective recruitment strategy. Although signaling theory is broadly applied and simple to understand, Ehrhart and Ziegert (2005) criticize its lack of in-depth explanation about which variables are the most influential factors at specific stages of the recruiting process. Therefore, more research needs to be carried out to identify the most influential factors on JPI, which is one of the stages of the recruiting process.

\subsection{Job Pursuit Intention - JPI}

There have been many attempts to define the precise meaning of JPI, and there seems to be a range of perspectives on the topic. In one of the earlier works on this topic, JPI is defined as a candidate's intention to apply for a vacant position or still remain in the application processing (Rynes et al., 1991). Meanwhile, per the definition by Chapman et al. (2005), JPI is an outcome variable, which measures an applicant's decision or desire to participate or remain in the pool of candidates without job choice commitment. AimanSmith et al. (2001) define JPI as the applicant's willingness to search more information about a firm, stay in touch with the firm, explore more about the firm, and regard the firm as a great place to work for. Although these definitions vary, the definition of JPI above can be summarized in the following phrase: "the intention of applicant to pursue job opportunities with a possible future organization".

\subsection{Compensation and JPI}

Previous studies have indicated that salary and benefits are perceived to be the most vital factors in association with career choice of students (Lewis et al., 2001; Malka \& Chatman, 2003) and considered as key variables determining JPI. Aiman-Smith et al. (2001) found that pay appears to be the strongest predictor of JPI that decides whether prospective applicant would like to pursue a job within the organization. Wayne and Casper (2012) indicate that company with good reputation on diversity efforts, workfamily, and compensation impacts student's JPI because they assume that company with high prestige will provide assistance and improve employee performance. Among three factors of human resources policies, compensation appears to have the strongest relationship with JPI, followed by work-family and diversity efforts.

In another study conducted in Malaysia, Ahmad et al. (2012) examine the influence of direct financial compensation including wage, salary and incentives, and bonus on career choice of students in hospitality industry. The descriptive analysis and multiple regression analysis reveal that all there dimensions affect career choice intention significantly. Likewise, Verwaeren et al. (2017) endeavor to examine the effect of compensation and benefits on JPI of high-profile applicants. The results show that providing complete and clear information on compensation and benefits directly affects applicant's JPI, and these relationships are fully mediated by perception of person-reward fit. Conversely, providing ambiguous information on compensation benefits affect negatively JPI of applicants. Moreover, compensation information in job advertisement, not only allow job seekers to shape the perceptions of suitability of compensation and benefit package, but also enable them to make deduction 
about other organizational attributes such as practices, values and philosophy.

Mohammed (2018) has conducted a study investigating students' intention to join the hotel industry in Malaysia and found significant relationships between pay and benefits and intention to join hotel industry. When the level of pay and benefits is higher, the career pursuit intention of hospitality students is stronger. In the same line with this study, Chang and Tanford (2018) assert that, when being exposed to a job advertisement of a specific company, compensation appears to be the most influential factor on JPI. With regard to individuals working in the IT industry, Dutta et al. (2019) also find that pay has positive effect on JPI of applicants in all career stages including exploration stage, establishment stage and maintenance stage. Therefore, these findings suggest a relationship between compensation and JPI of job seekers; the following hypothesis is proposed:

H1. Compensation has a significant influence on JPI of job seekers

\subsection{Work-life balance and JPI}

Family and professional life are two crucial planes of human functioning, which absorb time and energy. Often, the reconciling of different roles arising from functioning at home and at work generates conflicts. This is why the question of balance between work and life outside work including such areas as family, self-development, recreation, hobbies, etc., is essential. Dabirian et al. (2017) affirm that work-life balance as a proper balance between work and family facilitates employee to work in harmony with all the multiple identities of an individual. A good balance between social life and work allows employees to work more productively. Firfiray and Mayo (2017) indicate that work-life balance package may consist of the following benefits: elder care, wellness programs, time/ schedule, and child-related policies. They add that, based on work-life balance practices and polices provided by the organization, job seekers will develop high expectation that their organization will support them if they encounter difficulties in balancing their work and non-work aspects of their lives. As a result, it encourages them to pursue job with the organization (Firfiray \& Mayo, 2017). On the contrary, employees distracted by work-life balance practices lead to many issues such as increasing medical expenses, disengagement and absenteeism, and productivity loss. As a consequences, work-life balance has big influence on business revenue and business development (SánchezHernández et al., 2019).

Work-life balance has been proved to have positive relationship with JPI in several studies (Casper \& Buffardi, 2004). Not only affecting applicant's decision to apply for jobs, but work-life balance practices also result in great organizational outcomes such as sustainable and productive workplaces, enhanced organizational commitment, better work performance, and reduced turnover intentions (Beauregard \& Henry, 2009; Madhavkumar, 2016; Stavrou \& Ierodiakonou, 2016; Uggerslev et al., 2012). With regard to women, work-life balance is important to retain them in the labor market and motivate them to pursue higher positions (Mustapa et al., 2018). Casper and Buffardi (2004) reveal that dependent care assistance and work schedule flexibility are positively related to JPI. These signal that the company provides a great support to their employees. According to the study by Catanzaro et al. (2010), the findings show that the majority of male and female prefer to work for supportive organization, even receiving lower payment, because they believe that working in a supportive environment would allow them to balance work with life, and their personal life does not require a sacrifice. Although work-family practices are believed to be effective in attracting applicants with families, in the study by Wayne and Casper (2012), it makes a significant contribution to the body of knowledge with finding that work-family policies are so important to job seekers, even first-time job seekers without family responsibilities.

Likewise, Sánchez-Hernández et al. (2019) have found that young generations are more attracted to organizations providing work-life balance benefits, specifically work flexibility. Additionally, when investigating the factors influencing JPI of engineering and management students in India, Kumari and Saini (2018) find that provision of career growth opportunities is the most important factor with the highest effect on JPI of job seekers, followed by work-life benefits with medium effect, and corporate social responsibility with the lowest effect. More recent evidence from the study of Sharma and Prasad (2018) also claims the significant relationship between work-life balance and JPI (Sharma \& Prasad, 2018). Based on these findings, the following hypothesis is proposed:

H2. Work-life balance has a significant influence on JPI of job seekers.

\subsection{Corporate social responsibility and JPI}

In the employment context, corporate social responsibility has been proved to have significant relationship with recruitment (Highhouse et al., 2007). Besides, organizations actively engaging in corporate social responsibility are usually rewarded with improved financial performance (Porter \& Miles, 2013; Turner et al., 2019), increased employee commitment (Brammer et al., 2007), enhanced reputations (Brammer \& Pavelin, 2006), enhanced brand equity (Zahari et al., 2020), strengthened brand images 
(Lamond et al., 2010) and higher success in recruiting, selecting, and retaining employees (Catano \& Morrow Hines, 2016; Turner et al., 2019).

According to signaling theory, corporate social responsibility is regarded as one of the most attractive job attributes towards job seekers by signaling a company's workplace values, norms, business standards and working conditions (Greening \& Turban, 2000). Therefore, applicants prefer to pursue and accept job offers from organization with strong corporate social responsibility values (Catano \& Morrow Hines, 2016). Accordingly, Chaudhary (2018) postulates that environmental aspect of corporate social responsibility which is called green human resource management (GHRM) affect potential employee's JPI and organizational prestige was found to mediate the above relation.

Tsai et al. (2014) have developed a research model testing the relationship between four dimensions of corporate social responsibility (e.g., economic citizenship, legal citizenship, ethical citizenship, and philanthropic citizenship) and JPI among master students from two universities in Taiwan. A positive linkage between corporate social performance and JPI was found. However, with different levels of socioenvironmental consciousness, the levels of their relationship also change (Tsai et al., 2014). This result is consistent with Wang's study (2013), which promulgates that job seekers have a tendency to pursuit job and recommend other people to apply for vacant positions at organizations practicing CSR initiatives.

Dawkins et al. (2016) find that corporate social responsibility influences job choice intentions of Lebanese, Chinese and American college students. In their study, the authors also investigate the moderating effect of perceived behavioral control, subjective norm and attitudes toward CSR. Although students from all three countries are attracted to work for socially-responsible organizations, their intentions are derived in different ways. Based on these findings, it is suggested that organizations should tailor corporate socialresponsibility practices suitably to be able to attract potential applicants. Moorthy et al. (2017) have conducted a study on the "Influence of corporate social responsibility in JPI among prospective employees in Malaysia" to investigate how five dimensions of corporate social responsibility, e.g., environmental responsibility, philanthropic responsibility, ethical responsibility, legal responsibility, and workplace economic responsibility have different impact on job seeker's JPI. The study has found a significantly positive relationship between four out of the five CRS dimensions, with ethical responsibility being the exception. Therefore, organizations should pay more attention on corporate social responsibility practices as it assists in creating a competitive advantage to better attract talents. These findings further suggest a potential positive association between corporate social responsibility and JPI. So, we proposed the following hypothesis:

H3. Corporate social responsibility has a significant influence on JPI of job seekers.

\subsection{Career advancement and JPI}

Career advancement is defined as promotion to higher position with increased responsibility or higher levels in the organizational hierarchy (Hall, 2002). Employees receiving career advancement can grow professionally which enable them to move linearly, horizontally or vertically and therefore advance in their careers (Jáuregui \& Olivos, 2018). $\mathrm{Ng}$ et al. (2010) have investigated the career expectations of "millennial" generation (people born in the 1980s) and compared the perceptions of different race, gender, year of study and academic performances. The findings show that among four factors: nurturing work environment, meaningful work experiences, prospect of rapid advancement, and good pay and benefits, millennials rated prospect of rapid advancement as the first priority. This confirms their impatient and ambitious nature. As a result, in order to attract millennials, organizations should groom younger generation by providing more opportunities for promotion.

In the same line, Chang and Tanford (2018) reveal that, when being exposed to various job advertisements with the same pay levels, respondents are more likely to pay attention to advancement prospect. Kumari and Saini (2018) indicate that provision of career growth opportunities is the most important factor with the highest effect on JPI of job seekers, followed by work-life benefits with medium effect and corporate social responsibility with the lowest effect. In essence, promotion desire is obvious motivation to any worker, especially to undergraduate students as it is regarded as buffer for them to obtain specialized skills for their future job. Moreover, the research by Arijs et al. (2018) and Mohammed (2018) show the significant relationship between career advancement and JPI. Although this relationship has been experimented in many studies, the research subjects were mainly students. Therefore, further research is needed to investigate the perspectives of experienced employees. In this study, it is argued that has a positive influence on JPI. We proposed the following hypothesis:

H4. Career advancement has a significant influence on JPI of job seekers.

Resulting from the above analysis, a research model with four independence factors, including compensation, work-life balance, career advancement, and corporate social responsibility, and one dependence factor as JPI is illustrated below: 


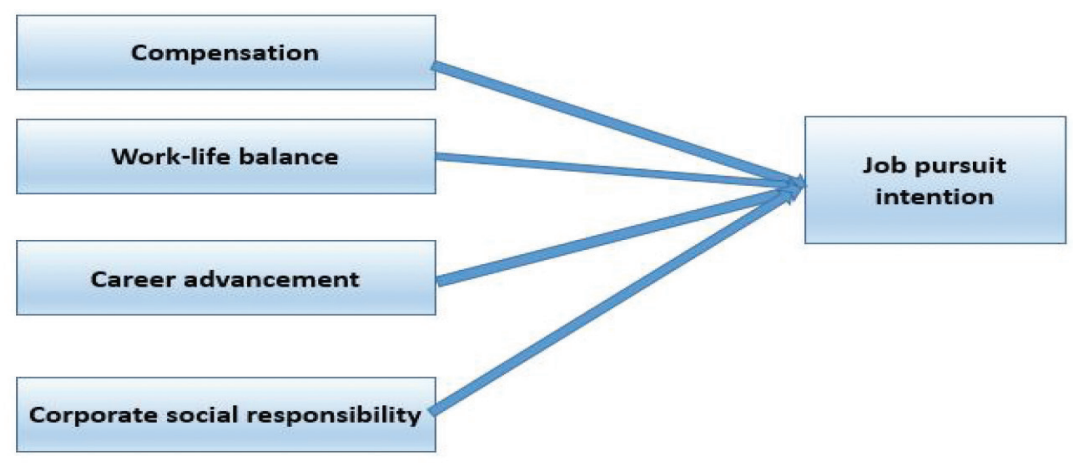

Figure 1: The research model

Table 1: Demographic analysis

\begin{tabular}{|l|c|c|}
\hline \multicolumn{1}{|c|}{ Items } & Amounts & Ratio \\
\hline Gender & 180 & $59.60 \%$ \\
\hline Female & 122 & $40.40 \%$ \\
\hline Male & $\mathbf{3 0 2}$ & $\mathbf{1 0 0 \%}$ \\
\hline Total & \multicolumn{2}{|}{} \\
\hline Hotels & 80 & $26.49 \%$ \\
\hline Park Hyatt Saigon & 102 & $33.77 \%$ \\
\hline The Reverie Saigon & 120 & $39.74 \%$ \\
\hline Sofitel Saigon Plaza & $\mathbf{3 0 2}$ & $\mathbf{1 0 0 \%}$ \\
\hline Total & 30 & $9.93 \%$ \\
\hline Age & 106 & $35.10 \%$ \\
\hline Age $<21$ & 122 & $40.40 \%$ \\
\hline $22 \leq$ Age $<25$ & 44 & $14.57 \%$ \\
\hline $25 \leq$ Age $<28$ & $\mathbf{3 0 2}$ & $\mathbf{1 0 0 \%}$ \\
\hline Age $\geq 28$ & & \\
\hline Total & & \\
\hline
\end{tabular}

\section{Research Methodology}

The study uses two types of secondary data and primary data with qualitative and quantitative research methods.

- For the secondary data, the published journals, books and other sources like websites, businesses' reports, etc., and content analysis of signaling theory have been used to determine factors affecting JPI of employees in Ho Chi Minh City.

- For the primary data, some techniques and tools are completed under the qualitative and quantitative modes. Firstly, the authors organized consultations with 10 experts including researchers and university administrators for the exploration of the hidden factors and measurement scales for the study. Furthermore, group discussions and five in-depths structured interviews have been conducted with 15 random employees working at five-star hotels to gain a deep understanding of the observed variables as a crosscheck for better results. Then, the questionnaire is built as the key tool to collect data. The questionnaire content is adapted from previous studies as listed in the table of summary of independence factors. Before launching out the official survey, pilot tests have been done with 30 employees to check comprehensibility and deliver feedback to improve the clarity of the questionnaire (see Table 1). 
Table 2: Cronbach's Alpha coefficients of the scales

\begin{tabular}{|c|c|c|c|c|}
\hline Items & $\begin{array}{l}\text { Scale Mean if } \\
\text { Item Deleted }\end{array}$ & $\begin{array}{l}\text { Scale Variance if } \\
\text { Item Deleted }\end{array}$ & $\begin{array}{l}\text { Corrected } \\
\text { Item - Total } \\
\text { Correlation }\end{array}$ & $\begin{array}{c}\text { Cronbach's Alpha if Item } \\
\text { Deleted }\end{array}$ \\
\hline Compensation (C) & & & & Cronbach's Alpha $=\mathbf{0 . 8 8 3}$ \\
\hline C1 & 10.50 & 5.620 & 0.655 & 0.890 \\
\hline $\mathrm{C} 2$ & 10.43 & 6.106 & 0.650 & 0.884 \\
\hline $\mathrm{C} 3$ & 10.37 & 5.530 & 0.852 & 0.810 \\
\hline C4 & 10.37 & 5.530 & 0.852 & 0.810 \\
\hline Career advancement (CA) & & & & Cronbach's Alpha $=0.776$ \\
\hline CA1 & 8.01 & 5.076 & 0.398 & 0.812 \\
\hline CA2 & 8.69 & 4.860 & 0.625 & 0.708 \\
\hline CA3 & 8.40 & 3.689 & 0.711 & 0.645 \\
\hline CA4 & 8.45 & 4.394 & 0.624 & 0.698 \\
\hline Work-life balance (WLB) & & & & Cronbach's Alpha $=\mathbf{0 . 8 5 3}$ \\
\hline WLB1 & 10.49 & 7.806 & 0.467 & 0.897 \\
\hline WLB2 & 10.73 & 6.137 & 0.824 & 0.758 \\
\hline WLB3 & 10.69 & 5.476 & 0.864 & 0.733 \\
\hline WLB4 & 10.40 & 6.527 & 0.650 & 0.832 \\
\hline \multicolumn{4}{|c|}{ Corporate social responsibility (CSR) } & Cronbach's Alpha $=0.847$ \\
\hline CSR1 & 11.10 & 5.950 & 0.641 & 0.824 \\
\hline CSR2 & 11.19 & 6.209 & 0.645 & 0.823 \\
\hline CSR3 & 11.32 & 5.549 & 0.704 & 0.797 \\
\hline CSR4 & 11.32 & 5.482 & 0.751 & 0.776 \\
\hline Job pursuit intension (JPI) & & & & Cronbach's Alpha $=0.769$ \\
\hline JPI1 & 10.55 & 5.544 & 0.468 & 0.763 \\
\hline JPI2 & 10.87 & 4.894 & 0.588 & 0.703 \\
\hline JPI3 & 10.71 & 5.044 & 0.621 & 0.689 \\
\hline JPI4 & 10.99 & 4.362 & 0.615 & 0.691 \\
\hline
\end{tabular}

Themain research rigor of this study is on thepost-positivism direction and Hair (2007) states the sample size should be as N $=5 *$ item (where item means observed variables). Meanwhile, Tabachnick and Fidell (2013) confirm the sample size should be as $\mathrm{N}=8 * \mathrm{var}+50$ (where var means independence variables used in the regression model). According to the sampling formula, the appropriate sample size should be 180 . However, this study uses the larger sample size because it helps to increase power and decrease estimation error (Van Voorhis \& Morgan, 2007). A total of 330 self-administered questionnaire were distributed to employees working in three five-stars hotel in Ho Chi Minh City. Consequently, the number of valid and completed questionnaires is 302 . The sampling technique is the convenience technique. The data is then processed with statistical techniques as Cronbach's Alpha, EFA, T-Test, ANOVA, etc. for answering research questions (see Table 2).

\section{Findings and Discussions}

The reliability of instruments was checked by computing the Cronbach's Alpha coefficient and corrected item total correlation. Cronbach's Alpha reliability coefficient normally ranges between 0 and 1. The closer Cronbach's Alpha coefficient is to 1.0 , the greater the internal consistency of the items in the scale (Gliem \& Gliem, 2003). In this study, Cronbach's Alpha coefficient for all factors was above 0.77 , indicating satisfactory internal consistency of the items in the scale. In addition, the item-total correlation of all items was over 0.3 , which indicates that the corresponding item correlates very well with the scale overall. Based on these two tests, the factor analysis was considered to be appropriate for the measurement scale.

Anumber of authors propose the retention of variables with factor loading above 0.5 for further analysis (Jayawardhena, 2004). A factor analysis was performed on the 24 survey items. Consequently, all items had a factor loading more than 0.5 . Therefore, the dimensions were named compensation, career advancement, work-life balance, corporate social responsibility and JPI.

The results show the significant positive effects of compensation, career advancement, work-life balance 
on JPI $(\mathrm{p}<0.05)$. However, there is no significant relationship between corporate social responsibility and JPI. Subsequently, a regression analysis is performed to determine which independent variables have the most effect on a dependent variable (see Table 3 and 4).

The result shows that the compensation, work-life balance, and career advancement factors are positively linked with JPI of hospitality employees in Ho Chi Minh City, Vietnam. However, compensation has the highest effect on job seeker's JPI. Finally, the linear regression equation is as follows:
$\mathrm{JPI}=0.563 * \mathrm{C}+0.208 * \mathrm{WLB}+0.240 * \mathrm{CA}$. On the other hand, the regression equation was not auto correlated.

The result of this study identifies three factors affecting JPI of hospitability employees in Ho Chi Minh City, namely, compensation, work-life balance, and career advancement. Meanwhile, there is no significant relationship between corporate social responsibility and JPI. Among three factors, compensation appears to be the most influential factor on JPI with the largest $\beta$ coefficient at 0.536 , followed by career advancement, then work-life balance (see Table 5).

Table 3: Correlations

\begin{tabular}{|c|c|c|c|c|c|c|}
\hline & & C & CA & CSR & WLB & JPI \\
\hline C & $\begin{array}{l}\text { Person Correlation } \\
\text { Sig. (2-tailed) } \\
\mathrm{N}\end{array}$ & $\begin{array}{c}1 \\
302 \\
\end{array}$ & $\begin{array}{c}.221^{* *} \\
0.000 \\
302\end{array}$ & $\begin{array}{c}-0.014 \\
0.811 \\
302\end{array}$ & $\begin{array}{l}.363^{* *} \\
0.000 \\
302\end{array}$ & $\begin{array}{c}.688^{* *} \\
0.000 \\
302\end{array}$ \\
\hline CA & $\begin{array}{l}\text { Person Correlation } \\
\text { Sig. (2-tailed) } \\
\mathrm{N}\end{array}$ & $\begin{array}{c}.221^{* *} \\
0 \\
302 \\
\end{array}$ & $\begin{array}{c}1 \\
302 \\
\end{array}$ & $\begin{array}{c}0.005 \\
0.924 \\
302 \\
\end{array}$ & $\begin{array}{c}.144^{*} \\
0.012 \\
302 \\
\end{array}$ & $\begin{array}{c}.364^{* *} \\
0 \\
302 \\
\end{array}$ \\
\hline CSR & $\begin{array}{l}\text { Person Correlation } \\
\text { Sig. (2-tailed) } \\
\mathrm{N}\end{array}$ & $\begin{array}{c}-0.014 \\
0.811 \\
302 \\
\end{array}$ & $\begin{array}{c}0.005 \\
0.924 \\
302 \\
\end{array}$ & $\begin{array}{c}1 \\
302 \\
\end{array}$ & $\begin{array}{c}-.119^{*} \\
0.039 \\
302 \\
\end{array}$ & $\begin{array}{c}0.04 \\
0.487 \\
302 \\
\end{array}$ \\
\hline WLB & $\begin{array}{l}\text { Person Correlation } \\
\text { Sig. (2-tailed) } \\
\mathrm{N}\end{array}$ & $\begin{array}{c}.363^{* *} \\
0 \\
302\end{array}$ & $\begin{array}{c}.144^{*} \\
0.012 \\
302\end{array}$ & $\begin{array}{c}-.119^{*} \\
0.039 \\
302\end{array}$ & $\begin{array}{c}1 \\
302 \\
\end{array}$ & $\begin{array}{c}.451^{* *} \\
0 \\
302\end{array}$ \\
\hline JPI & $\begin{array}{l}\text { Person Correlation } \\
\text { Sig. (2-tailed) } \\
\mathrm{N}\end{array}$ & $\begin{array}{c}.688^{* *} \\
0 \\
302 \\
\end{array}$ & $\begin{array}{c}.364^{* *} \\
0 \\
302 \\
\end{array}$ & $\begin{array}{c}0.04 \\
0.487 \\
302 \\
\end{array}$ & $\begin{array}{c}.451^{* *} \\
0 \\
302\end{array}$ & $\begin{array}{c}1 \\
302\end{array}$ \\
\hline
\end{tabular}

**. Correlation is significant at the 0.01 level (2-tailed).

*. Correlation is significant at the 0.05 level (2-tailed).

Table 4: Model summary

\begin{tabular}{|l|c|c|c|c|c|}
\hline Model & $\mathbf{R}$ & R Square & Adjusted R Square & Std. Error of the Estimate & Durbin-Watson \\
\hline 1 & $.759^{a}$ & 0.575 & 0.571 & 0.46853 & 2.071 \\
\hline
\end{tabular}

a. Predictors: (Constant), career advancement, work-life balance, compensation

b. Dependent Variable: job pursuit intention

Table 5: Regression results of the model

\begin{tabular}{|c|c|c|c|c|c|c|c|c|}
\hline \multicolumn{9}{|c|}{ Coefficients $^{a}$} \\
\hline \multirow{2}{*}{\multicolumn{2}{|c|}{ Model }} & \multicolumn{2}{|c|}{$\begin{array}{l}\text { Unstandar dized } \\
\text { Coefficients }\end{array}$} & \multirow{2}{*}{$\begin{array}{c}\text { Standardized } \\
\text { Coefficients }\end{array}$} & \multirow[t]{2}{*}{$\mathbf{t}$} & \multirow{2}{*}{ Sig. } & \multicolumn{2}{|c|}{ Collinearity Statistics } \\
\hline & & B & Std.Error & & & & Tolerance & VIF \\
\hline \multirow{4}{*}{1} & (Constant) & .446 & .167 & & 2.664 & .008 & & \\
\hline & Compensation & .491 & .038 & .536 & 12.772 & .000 & .809 & 1.237 \\
\hline & Work-life balance & .187 & .037 & .208 & 5.045 & .000 & .838 & 1.194 \\
\hline & Career advancement & .270 & .045 & .240 & 6.012 & .000 & .891 & 1.123 \\
\hline
\end{tabular}

a. Dependent Variable: Job pursuit intention 
The strong effect of compensation on job seeker's JPI may be explained by the collectivist culture in Vietnam. The collectivist culture of Vietnam originated from the Confucianism which stresses the significant important role of family and community and where interdependence is accentuated (Cook \& Timberlake, 1984). Confucianism believes that family has to be kept at the center of every individual's life (Doan, 1999). It is expected that each member of the family adheres to specific hierarchical roles, with a focus on Confucian concepts of filial piety and order. Therefore, job seekers are more likely to attach higher importance to attributes regarding compensation, so that they can support their family by nurturing the young, cherishing and looking after the elderly. Additionally, job seekers also have a tendency to pay more attention to work-life balance and career advancement attributes when pursuing a vacant position. These results are consistent with previous studies (Dutta et al., 2019; Firfiray \& Mayo, 2017; Kumari \& Saini, 2018) The findings of this study can assist organizations in better understanding the perceptions of prospective applicants in order to develop more effective policies, practices and strategies in accordance to their target group (Alnıaçık et al., 2014). Therefore, in order to attract more job seekers to apply for vacant positions and avoid losing the high-quality labor force, hoteliers in Ho Chi Minh City should develop recruitment strategy that provides employees with high compensation, improved career advancement, and work-life policies.

\section{Conclusions}

Based on the argument of signaling theory associated with utilizing qualitative and quantitative research approaches, this study reveals three factors that have significant influence on job seeker's JPI, namely: compensation, work-life balance, and career advancement. As a result, these findings suggest hospitality organizations should integrate these practices into recruiting initiatives, especially emphasize compensation package that employees will receive when working for the organization, as it is the most important factor on JPI.

In terms of theoretical implications, the study helps to deepen and expand the existing literature on JPI in various contexts. Job seekers from different countries or industries may have different perspectives about which factors affect their pursuit intention. Therefore, more research is needed to investigate organizational attributes attractive to employees.

In terms of practical implications, these findings suggest that organizations in hotel industry must communicate the right sets of job attributes associated with attractive compensation package, work-life balance policies, and promotion opportunities to potential employees if they wish to attract a larger pool of applicants. Enlarging the pool of candidates is worthwhile as it increases the possibility that the most qualified applicants will eventually be recruited. However, during the early recruitment phase, it is difficult for potential employees to obtain the full information from their future employers. Therefore organizations should attempt to reflect these practices favorably and accurately through corporate websites and other recruitment materials.

This study has some limitations. Firstly, as this study adopted the convenience sampling method the generalizability is a limitation. Future studies can be carried out in different contexts to identify appropriate factors in each context. Secondly, this study developed a research model that involves the direct effects of four elements only (i.e., compensation, work-life balance, career advancement, and corporate social responsibility) on JPI, further research can investigate more factors and test their association. Thirdly, although these factors have an influence on JPI, the research investigating the mediating and moderating variables underlying these relationships is still very rare. Therefore, more studies are necessary to gain the systematic and deep understanding about job seeker's perspective about their employer of choice.

\section{References}

Alnıaçık, E., Alnıaçı, Ü., Erat, S., \& Akçin, K. (2014). Attracting talented employees to the company: Do we need different employer branding strategies in different cultures? ProcediaSocial And Behavioral Sciences, 150, 336-344.

Ambler, T., \& Barrow, S. (1996). The employer brand. Journal of Brand Management, 4(3), 185-206.

Backhaus, K., \& Tikoo, S. (2004). Conceptualizing and researching employer branding. Career Development International, 9(5), 501-517.

Beauregard, T. A., \& Henry, L. C. (2009). Making the link between work-life balance practices and organizational performance. Human Resource Management Review, 19(1), 9-22.

Berthon, P., Ewing, M., \& Hah, L. L. (2005). Captivating company: dimensions of attractiveness in employer branding. International Journal of Advertising, 24(2), 151-172.

Brammer, S., Millington, A., \& Rayton, B. (2007). The contribution of corporate social responsibility to organizational commitment. The International Journal of Human Resource Management, 18(10), 1701-1719.

Brammer, S. J., \& Pavelin, S. (2006). Corporate reputation and social performance: The importance of fit. Journal of Management Studies, 43(3), 435-455.

Cable, D. M., \& Turban, D. B. (2003). The value of organizational reputation in the recruitment context: A brand-equity perspective. Journal of Applied Social Psychology, 33(11), 2244-2266.

Casper, W. J., \& Buffardi, L. C. (2004). Work-life benefits and job pursuit intentions: The role of anticipated organizational support. Journal of Vocational Behavior, 65(3), 391-410. 
Catano, V. M., \& Morrow Hines, H. (2016). The influence of corporate social responsibility, psychologically healthy workplaces, and individual values in attracting millennial job applicants. Canadian Journal of Behavioural Science, 48(2), 142.

Celani, A., \& Singh, P. (2011). Signaling theory and applicant attraction outcomes. Personnel Review, 40(2), 222-238.

Chang, W., \& Tanford, S. (2018). The impact of job advertising on hospitality graduates' job pursuit intention. Journal of Hospitality \& Tourism Education, 30(4), 215-228.

Cook, K., \& Timberlake, E. (1984). Working with Vietnamese refugees. Social Work, 29(2), 108-113.

Doan, P. (1999). Some issues on Vietnamese Confucianism. Hanoi, Vietnam: Publishing House of National Politics.

Dutta, D., Mishra, S. K., \& Varma, A. (2019). Predictors of job pursuit intention across career stages: a multi-phase investigation. The International Journal of Human Resource Management, 1-38. https://doi.org/10.1080/09585192.2019.16 51376

Ehrhart, K. H., \& Ziegert, J. C. (2005). Why are individuals attracted to organizations? Journal of Management, 31(6), 901-919.

Firfiray, S., \& Mayo, M. (2017). The lure of work-life benefits: Perceived person-organization fit as a mechanism explaining job seeker attraction to organizations. Human Resource Management, 56(4), 629-649.

George, C., Omuudu, O. S., \& Francis, K. (2020). Employee engagement: a mediator between organizational inducements and industry loyalty among workers in the hospitality industry in Uganda. Journal of Human Resources in Hospitality \& Tourism, 19(2), 220-251. https://doi.org/10.1080/15332845.2 020.1702869

Greening, D. W., \& Turban, D. B. (2000). Corporate social performance as a competitive advantage in attracting a quality workforce. Business \& Society, 39(3), 254-280.

Hall, D. T. (2002). Careers in and out of organizations. Thousand Oaks, CA: Sage Publications.

Highhouse, S., Thornbury, E. E., \& Little, I. S. (2007). Socialidentity functions of attraction to organizations. Organizational Behavior and Human Decision Processes, 103(1), 134-146.

Jain, N., \& Bhatt, P. (2015). Employment preferences of job applicants: unfolding employer branding determinants. Journal of Management Development, 34(6), 634-652. https://doi. org/10.1108/JMD-09-2013-0106

Jáuregui, K., \& Olivos, M. (2018). The career advancement challenge faced by female executives in Peruvian organisations. BAR-Brazilian Administration Review, 15(4).

Jayawardhena, C. (2004). Measurement of service quality in internet banking: the development of an instrument. Journal of Marketing Management, 20(1-2), 185-207.

Kumari, S., \& Saini, G. K. (2018). Do instrumental and symbolic factors interact in influencing employer attractiveness and job pursuit intention? Career Development International, 23(4), 444-462.
Lamond, D., Dwyer, R., Arendt, S., \& Brettel, M. (2010). Understanding the influence of corporate social responsibility on corporate identity, image, and firm performance. Management Decision, 48(10), 1469-1492. https://doi. org/10.1108/00251741011090289

Lewis, D., Brazil, K., Krueger, P., Lohfeld, L., \& Tjam, E. (2001). Extrinsic and intrinsic determinants of quality of work life. Leadership in Health Services, 14(2), ix-xv.

Madhavkumar, V. (2016). Job attributes influencing job pursuit intention of Gen Y MBA students: Investigation. SCMS Journal of Indian Management, 13(2), 96-105.

Malka, A., \& Chatman, J. A. (2003). Intrinsic and extrinsic work orientations as moderators of the effect of annual income on subjective well-being: A longitudinal study. Personality and Social Psychology Bulletin, 29(6), 737-746.

Mustapa, N. S., Noor, K. M., \& Mutalib, M. A. (2018). Why can't we have both? A discussion on work-life balance and women career advancement in Malaysia. Journal of Asian Finance, Economics and Business, 5(3), 103-112. http://doi. org/10.13106/jafeb.2018.vol5.no3.103

Porter, T., \& Miles, P. (2013). CSR longevity: Evidence from longterm practices in large corporations. Corporate Reputation Review, 16(4), 313-340.

Rynes, S. L., Bretz Jr, R. D., \& Gerhart, B. (1991). The importance of recruitment in job choice: A different way of looking. Personnel Psychology, 44(3), 487-521.

Sánchez-Hernández, M. I., González-López, Ó. R., BuenadichaMateos, M., \& Tato-Jiménez, J. L. (2019). Work-Life Balance in Great Companies and Pending Issues for Engaging New Generations at Work. International Journal of Environmental Research and Public Health, 16(24), 5122.

Sharma, R., \& Prasad, A. (2018). Employer brand and its unexplored impact on intent to join. International Journal of Organizational Analysis, 26(3), 536-566.

Stavrou, E., \& Ierodiakonou, C. (2016). Entitlement to work-life balance support: Employee/manager perceptual discrepancies and their effect on outcomes. Human Resource Management, 55(5), 845-869.

Tanwar, K., \& Prasad, A. (2017). Employer brand scale development and validation: a second-order factor approach. Personnel Review, 46(2), 389-409.

Tsai, Y.-H., Joe, S.-W., Lin, C.-P., \& Wang, R.-T. (2014). Modeling job pursuit intention: Moderating mechanisms of socioenvironmental consciousness. Journal of Business Ethics, 125(2), 287-298.

Turner, M. R., McIntosh, T., Reid, S. W., \& Buckley, M. R. (2019). Corporate implementation of socially controversial CSR initiatives: Implications for human resource management. Human Resource Management Review, 29(1), 125-136.

Uggerslev, K. L., Fassina, N. E., \& Kraichy, D. (2012). Recruiting through the stages: A meta-analytic test of predictors of applicant attraction at different stages of the recruiting process. Personnel Psychology, 65(3), 597-660. 
Ul Islam, Z., Bangish, S. B., Muhammad, H., \& Jehan, A. S. (2016). The impact of HR practices on job satisfaction: A case study of hotel industry in Pakistan. Journal of Asian Finance, Economics and Business, 3(1), 43-48. https://doi.org/10.13106/ jafeb.2016.vol3.no1.43.

VanVoorhis, C. W., \& Morgan, B. L. (2007). Understanding power and rules of thumb for determining sample sizes. Tutorials in Quantitative Methods for Psychology, 3(2), 43-50.

Wang, Y. (2013). Corporate Reputation Management: Reaching Out to Financial Stakeholders. Doctoral thesis, Rotterdam University.

Williamson, I. O., Lepak, D. P., \& King, J. (2003). The effect of company recruitment web site orientation on individuals' perceptions of organizational attractiveness. Journal of Vocational Behavior, 63(2), 242-263.

Zahari, A. R., Esa, E., Rajadurai, J., Azizan, N. A., \& Muhamad Tamyez, P. F. (2020). The Effect of Corporate Social Responsibility Practices on Brand Equity: An Examination of Malaysia's Top 100 Brands. Journal of Asian Finance, Economics, and Business, 7(2), 271-280. https://doi. org/10.13106/jafeb.2020.vol7.no2.271

Zhu, F., Wang, Z., Yu, Q., Hu, T., Wen, Y., \& Liu, Y. (2014). Reconsidering the dimensionality and measurement of employer brand in the Chinese context. Social Behavior and Personality: An International Journal, 42(6), 933-948. 